\title{
Estimating the Impact of Trade Cost on Export: A Case Study Vietnam
}

\author{
Mai Thi Cam Tu ${ }^{1}$, Huynh Thi Thuy Giang ${ }^{2}$ \\ Received: April 3, 2018 Revised: June 29, 2018 Accepted: July 30, 2018
}

\begin{abstract}
The paper aims to investigate the impact of trade cost on export: A Case Study Vietnam. The study conducts a static linear panel data analysis on annual data covering bilateral export between Vietnam and 70 major importers of Vietnam from 2001 to 2013 . The gravity model has been one of the most successful applications in empirical trade. In this paper we apply the gravity model to estimate the impact of trade cost on Vietnamese bilateral export value. The paper uses gravity model to estimate the impact of trade cost on Vietnamese bilateral export value. The empirical results derive from a static linear panel data analysis (fixed effects model) indicates that trade cost plays a crucial role in determining the export value that occurs between Vietnam and trading partners. Besides, population of importing country, trade openness of importing country, gross domestic product of importing country and gross domestic product of Vietnam are also significant determinants of Vietnamese bilateral export value. The main findings indicates that trade cost plays a very important role in the Vietnamese bilateral export performance. This suggests that the Vietnamese government should attempt to improve domestic trade costs to enhance competitiveness and increase export growth sustainably.
\end{abstract}

Keywords: Vietnamese Export, Trade Cost, Export, Domestic Trade Cost, Asia, Vietnam.

JEL Classification Code: C33, F10, F13, F15.

\section{Introduction}

In international trade, the cost of production and the trade cost are two crucial factors that can affect competitiveness on an export growth particularly by developing countries raised by several researchers (i.e., Anderson \& Wincoop, 2004; Arvis et al., 2013; De, 2007; Obstfeld \& Rogoff, 2000). Nowadays, there is little difference in production cost between exporting countries. High trade costs constrain the economic advancement of many developing countries by impeding their ability to take full advantage of world markets (Roberts \& Janson, 2014). Therefore, the trade cost plays a very important role in export performance of exporting countries.

Vietnam is a country which has the advantage of exporting agricultural commodities and raw products to the world market. In 2016, the recorded highest jump in the export value was from 162.01 to 214.56 billion USD, increased $18.19 \%$ compared to the previous year. During

1 First Author and Corresponding Author. Professor, Faculty of International Economic Relations, University of Economics and Law, Vietnam National University - Ho Chi Minh City, Vietnam [Postal Address: Quarter 3, Linh Xuan Ward, Thu Duc District, Ho Chi Minh City, 760000, Vietnam] Email: tumtc@uel.edu.vn

2 Professor, Faculty of International Economic Relations, University of Economics and Law, Vietnam National University - Ho Chi Minh City, Vietnam, Email: gianghtt@uel.edu.vn
2001-2013, the average annual growth rate of export was comparatively remarkable with about $20.39 \%$. But the growth rate of export had been unstable over the last thirty years. The growth rate of export increased from $11.6 \%$ to $34.15 \%$ during $2001-2013$ and decreased by $8.92 \%$ in 2009 as compared to the previous year. As the export growth rate is not sustainability, it signals that Vietnam to seek for a suitable solution to boost the sustainability on an export growth again. According to Blancas et al. (2014), Vietnamese domestic trade cost estimated about at $20.9 \%$ Vietnamese GDP, while this cost in the world was about $15 \%$ world's GDP. It is higher than Thailand and Malaysia trade cost. This raise the question as follows: Does the trade cost has any effect on Vietnamese export performance?

There was an extensive string of studies analyzing the impact of distance on export in the past decades. Distance has been used as a proxy for international transport costs from the exporting country to the importing country. But what is less frequent is the impact of trade costs which pertain to and from the counterparts (Anderson \& Wincoop, 2004; Arivs et al., 2013; De, 2007; Khan \& Kalirajan, 2011). Especially in Vietnam, there has not yet studied focusing on the impact of trade cost on Vietnamese export. The paper attempts to fill the gap and estimates the impact of trade cost on Vietnamese bilateral export value in a panel framework based on static and dynamic gravity models. The 
findings are expected to help Vietnamese government improve domestic trade costs to enhance competitiveness and increase export growth sustainably.

The paper proceeds as follows: Section 2 Literature Review. Section 3 summarizes situations of Vietnamese export. Section 4 describes the econometric methodology and data used for the empirical analysis. Section 5 presents and interprets the main regression results, and Section 6 summarizes the study, suggest some policy implications and Limitations of the Study.

\section{Literature Review}

\subsection{Definition of Trade Cost}

Trade cost, amongst other determinants of the volume of trade, plays a significant role in determining the amount of trade of a nation. The well-known hypothesis of Obstfeld and Rogoff (2000) is that trade cost is the key to explaining all the major puzzles of international macroeconomics. Anderson and Wincoop (2004) also commented that it is very difficult to understand and measure the real costs involved in trade between countries. There are many studies on trade cost which define the costs incurred in each geographical region. Trade costs include all costs incurred in getting a good to a final user other than the marginal cost of producing the good itself, such as transportation costs (both freight costs and time costs), policy barriers (tariffs and non-tariff barriers), information costs, contract enforcement costs, costs associated with the use of different currencies, legal and regulatory costs, and local distribution costs (wholesale and retail) Anderson and Wincoop (2004). Unlike domestic trade, these costs are incurred in two different geographical regions; the costs incurred in the home country, and the costs incurred in the importing country.

Khan and Kalirajan (2011) decomposed trade costs into a number of components - natural costs, behind the border costs, implicit beyond the border costs and explicit beyond the border costs. In an attempt to investigate these notions in the absence of complete information on the home and partner countries, the authors conclude that the growth of export was mainly brought about by reduction of explicit and implicit beyond the border costs in partner countries.

According to Incoterms rules 2010, all costs incurred in the home and importing country, such as packaging cost, loading from warehouse cost, pre-carriage cost, export customs clearance cost, handling at departure cost, main transportation cost, transportation insurance cost, handling at arrival cost, import customs clearance cost, post-carriage cost and unloading into warehouse cost. Krugman et al. (2012) argued that the costs affected the export performance of the exporting country are export tariffs, non- tariff barriers for exports, exchange rates and export policies, the costs affect the import performance of the importing country are import duties, non-tariff, exchange rates and import policies. According to this paper approach, trade costs include all costs incurred in getting a good to a final user other than the marginal cost of producing the good itself. Unlike domestic trade, exporting is the act of producing goods or services in one country and selling or trading them to another country. Base on concept of export define, the trade costs consist of three main components as (i) the costs incurred in the exporting country, (ii) the costs incurred in the importing country and (iii) main transportation cost and transportation insurance cost.

$\mathrm{Pp}$ denotes marginal cost of producing per unit. Pc denotes final price that end user pays. ECi is the costs incurred in the exporting country which has main costs such as: Packaging cost, loading from warehouse cost, precarriage cost, export customs clearance cost, handling at departure cost, transaction costs and other costs. ECj is the costs incurred in the importing country which has main costs such as: Handling at arrival cost, import customs clearance cost, post-carriage cost and unloading into warehouse cost, transaction costs and other costs. ECt is the main transportation cost and transportation insurance cost.

The trade cost ECij $=E C i+E C t+E C j$.

The end user in the importing country generally pays $\mathrm{Pc}=$ $\mathrm{Pp}+\mathrm{ECij}$.

In today's international competition, the marginal costs of producing per unit $(\mathrm{Pp})$ are little different between exporting countries as the same natural conditions. Therefore, if the ECi of exporting country is lower than others, the competitive on export of the exporting country will be higher than others. In order to assess the relative importance of trade cost on export we need an appropriate theoretical framework. Regarding the economic literature, there are a lot of empirical approaches which have used the gravity model to explain the determinants of bilateral trade. The gravity model has been used extensively in the international trade literature in the past 50 years. The gravity model can today be considered standard procedure when a country's directions of trade are analyzed.

\subsection{The Gravity Model}

The gravity model was first applied to examine international trade flows by Tinbergen (1962). It is based on the Newton's law in physics, which equates the gravitational attraction between two objects to the product of their masses divided by the distance between them. The simplest form of gravity model in international trade is expressed as follows: 


$$
X_{i j}=\varphi\left(\frac{Y i * Y j}{\mathrm{Dij}}\right)
$$

In which, $X_{\mathrm{ij}}$ indicates the exports from country $\mathrm{i}$ to country j. Yi and $\mathrm{Yj}$ are the Gross Domestic Product (GDP) of countries $\mathrm{i}$ and $\mathrm{j}$. Dij measures the distance between country $\mathrm{i}$ and country $\mathrm{j}$; and $\varphi$ is a constant of proportionality. The gravity model assumes that there is a positive relationship between the bilateral trade and the size of a trading partner. A country tends to trade more with a larger partner, holding all other factors constant. The distance between partners is negatively linked to the bilateral trade. The greater the distance, the bigger the resistance to trade. The linear form of the model is as follows:

$$
\operatorname{Ln} X_{i j}=\beta_{0}+\beta_{1} \operatorname{Ln}\left(Y_{i}\right)+\beta_{2} \operatorname{Ln}\left(Y_{j}\right)-\beta_{3} \operatorname{Ln}(D i j)+\varepsilon
$$

While the gravity model has long been criticized for lack of theoretical underpinnings, since late 1970s, various attempts have been made to fill the theoretical gap (for example, Anderson, 1979; Bergstrand, 1989; Helpman, 1987). Recently, Deardorff (1995) and McCallum (1995) have showed that the gravity model can be justified from traditional trade theories. Besides, Anderson and Wincoop (2003) successfully derived an operational gravity model from the Constant Elasticity of Substitution (CES) system. Most estimates of gravity models add a certain number of dummy variables to (2) that test for specific effects, for example being a member of a trade agreement, sharing a common land border, speaking the same language and so on. Therefore, generalized gravity equation shortens from Tinbergen (1962) and Anderson and Wincoop (2003) is of the form:

$$
\begin{gathered}
\operatorname{Ln} X_{i j}=\beta_{0}+\beta_{1} \operatorname{Ln}\left(Y_{i}\right)+\beta_{2} \operatorname{Ln}\left(Y_{j}\right)-\beta_{3} \operatorname{Ln}(\mathrm{Dij}) \\
+\sum_{n=1}^{m} \beta_{4} \operatorname{Ln}\left(A_{i j}\right)+\varepsilon
\end{gathered}
$$

In which, $X_{i j}$ indicates the exports from country $i$ to country j. $Y i$ and $Y j$ are the Gross Domestic Product (GDP) of countries $\mathrm{i}$ and $\mathrm{j}$. Dij measures the distance between country i and country j. $A_{i j}$ represents other factors that could aid or impede exports between countries $\mathrm{i}$ and $\mathrm{j}$.

The gravity equation has continued to achieve empirical success in explaining bilateral flows and this explains why the gravity framework of trade is recognized as the workhorse in explaining bilateral trade flows. Most of the studies that have employed the gravity equation has sought to estimate various types of bilateral trade cost across countries and overtime.

\subsection{Recent Development in Trade Cost on Export}

A number of gravity model studies considering different time periods and assorted countries (including single country studies) with the employment of different methodologies have documented a negative relationship between trade cost and volume (or value) of exports (Anderson \& Wincoop, 2004; Arivs et al., 2013; De, 2007; Khan \& Kalirajan, 2011). While early literature peroxided trade cost by distance or as border variables (i.e., Kepaptsolou et al., 2010; McCallum, 1995; Tran \& Ngo, 2015; Pham \& Nguyen, 2015). Anderson and Wincoop (2004) dealt extensively with the trade cots and its impact on international trade. A rough estimate of the tax equivalent of "representative" trade costs for industrialized countries is $170 \%$. This number breaks down as follows: $21 \%$ transportation costs; $44 \%$ border related trade barriers, $55 \%$ retail and whole sale distributions costs.

De (2007) also used the gravity model to examine the impact of trade costs on trade: Empirical evidence from Asian countries. De (2007) observed that high trade costs are having an adverse impact on Asia's trade. High costs of trade are impacting trade of the region when trade interdependency in Asia is gaining momentum together with the reduction of tariff barriers. With freight costs substantially higher for the developing countries as compared to the developed ones, it is the case that freight costs in developing Asia are 116 per cent higher than in the developing countries. The paper also found evidence that increased auxiliary shipping charges are having an unfavourable impact when ocean freight prices are generally on the decline. De (2007) also estimated an augmented gravity model at the 4-digit HS level for the year 2004 to conclude that infrastructure quality, tariffs and transport costs affect trade patterns significantly in the Asian region. More specifically, the study concludes that a 10 per cent reduction in tariffs and transportation costs would increase bilateral trade by about 2 and 6 per cent respectively. Furthermore, other conclusions of the paper state that Asian neighbours have benefitted from FTAs and common language. The author also showed concerns regarding the poor infrastructure quality of the LDCs and states that their share in world trade would likely decrease if these countries continually lag behind the developed ones.

Khan and Kalirajan (2011) used the gravity model to examine the impact of trade cost in Pakistan. For empirical analysis, 79 countries of Pakistan's trade partners were selected during 1994-2004. The results showed that Pakistan's exported to some of its partner countries grew mainly due to the reduction in both 'explicit and implicit beyond the border' trade costs and due to increased demand in partner countries between 1999 and 2004. On 
the other hand, 'behind the border' trade costs within Pakistan have led to larger export losses in 2004 particularly with respect to China and India.

Arvis et al. (2013) has used newly collected data on international trade and production to infer estimates of trade costs for up to 167 countries over the period 1995-2012. Arvis et al. (2013) used the gravity model to estimates distinguish between trade in manufactured goods and trade in agricultural products. In both cases, they find that absolute levels of trade costs are highly significant in ad valorem equivalent terms, ranging from an average of just over $80 \%$ for high income countries in manufactures, to over $300 \%$ for low income countries in agriculture. Their results suggest that although the international economy has integrated considerably in recent decades, there remain potentially large unexploited gains to be reaped from further reducing the wedge between export and import prices. There is likely a consensus amongst authors that gravity equation is a useful tool to examine the impact of trade cost on trade. Hence, the author applies the equation (3) and proposes the model to estimate the impact of trade cost on export: A Case Study Vietnam.

\section{Overview of Vietnamese Exports}

According to Figure 1, Vietnamese export value is estimated at 15.02 billion, 132.03 billion and 214.56 billion in 2001, 2013, 2016. In 2016, the recorded highest jump in the export value was from 162.01 to 214.56 billion USD, increased $18.19 \%$ compared to the previous year. Vietnamese export value is uninterruptedly increase throughout the period (only exception in 2009). In 2009, the Vietnamese export was affected by the global economic turmoil. In 2009, all major markets fell into recession, which led to reduce demand for imported items. Indeed, in 2009 orders form US, Europe have dropped. According the exports to trading partners went down. The average growth rate of export is comparatively remarkable with about $20.39 \%$. But the average growth rate of export did not unstable increase year to year. In 2009, it decreased $8.92 \%$ compare to the previous year. As the export growth rate is not sustainability, it signals that Vietnam to seek for a suitable solution to boost the sustainability on an export growth again.

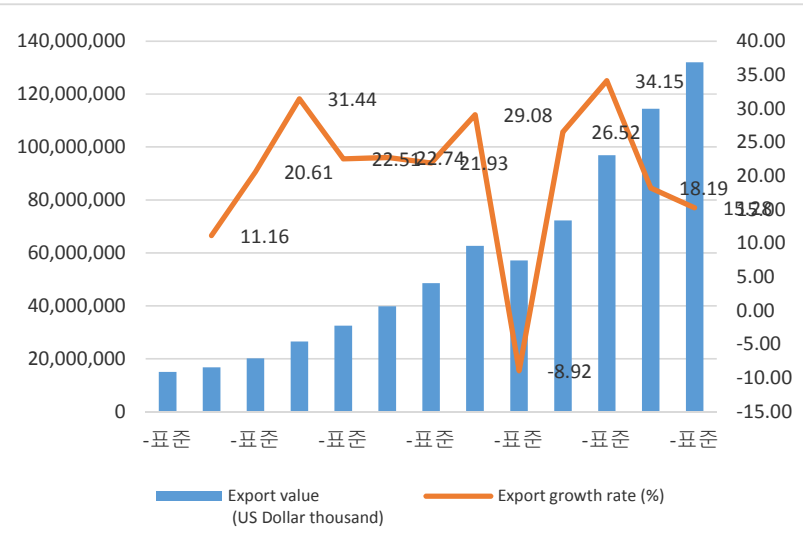

Source: Trade Map International Trade statistics

Figure 1. Value and export growth rate 2001-2013

Vietnam has clients from more 223 countries. There are about 15 markets located in different areas to which the exporting exceeds $70 \%$ total export value of Vietnam. The period from 2001 to 2013, the export value from United States, Japan, China, United Kingdom, Australia, Australia has a downward trend, from others countries has a rising trend in recent years (Table 1).

Table 1. Vietnam's Top 15 Trading Partners (Unit: Percentage of total Vietnam export)

\begin{tabular}{|l|l|l|l|l|l|l|l|l|l|l|l|l|l|}
\hline Year & $\mathbf{2 0 0 1}$ & $\mathbf{2 0 0 2}$ & $\mathbf{2 0 0 3}$ & $\mathbf{2 0 0 4}$ & $\mathbf{2 0 0 5}$ & $\mathbf{2 0 0 6}$ & $\mathbf{2 0 0 7}$ & $\mathbf{2 0 0 8}$ & $\mathbf{2 0 0 9}$ & $\mathbf{2 0 1 0}$ & $\mathbf{2 0 1 1}$ & $\mathbf{2 0 1 2}$ & $\mathbf{2 0 1 3}$ \\
\hline United States & 7.09 & 14.68 & 19.55 & 18.98 & 18.27 & 19.71 & 20.82 & 18.99 & 19.99 & 19.73 & 17.51 & 17.18 & 18.08 \\
\hline Japan & 16.7 & 14.59 & 14.44 & 13.37 & 13.38 & 13.16 & 12.54 & 13.51 & 11.1 & 10.7 & 11.45 & 11.41 & 10.26 \\
\hline China & 9.43 & 9.09 & 9.35 & 10.95 & 10.01 & 8.14 & 7.51 & 7.74 & 9.46 & 10.72 & 11.98 & 11.21 & 9.98 \\
\hline South Korea & 2.7 & 2.81 & 2.44 & 2.3 & 2.05 & 2.12 & 2.56 & 2.86 & 3.64 & 4.28 & 5.02 & 4.87 & 5.06 \\
\hline Malaysia & 2.24 & 2.08 & 2.25 & 2.36 & 3.17 & 3.05 & 3.2 & 3.24 & 3.11 & 2.9 & 2.86 & 3.93 & 3.78 \\
\hline Germany & 4.8 & 4.36 & 4.24 & 4.02 & 3.35 & 3.63 & 3.82 & 3.31 & 3.3 & 3.28 & 3.47 & 3.58 & 3.59 \\
\hline Hong Kong & 2.11 & 2.04 & 1.83 & 1.43 & 1.09 & 1.14 & 1.2 & 1.4 & 1.81 & 2.03 & 2.28 & 3.24 & 3.12 \\
\hline United Kingdom & 3.4 & 3.42 & 3.75 & 3.81 & 3.13 & 2.96 & 2.95 & 2.52 & 2.33 & 2.33 & 2.47 & 2.65 & 2.8 \\
\hline Australia & 6.93 & 7.95 & 7.05 & 7.12 & 8.39 & 9.26 & 7.83 & 6.94 & 4.18 & 3.74 & 2.69 & 2.8 & 2.64 \\
\hline Thailand & 2.15 & 1.36 & 1.66 & 1.96 & 2.66 & 2.25 & 2.12 & 2.06 & 2.3 & 1.64 & 2 & 2.47 & 2.32 \\
\hline Netherlands & 2.43 & 2.42 & 2.45 & 2.2 & 2.03 & 2.15 & 2.43 & 2.52 & 2.37 & 2.34 & 2.22 & 2.16 & 2.22 \\
\hline Cambodia & 0.97 & 1.07 & 1.33 & 1.45 & 1.71 & 1.96 & 2.14 & 2.44 & 2.04 & 2.16 & 2.6 & 2.56 & 2.22 \\
\hline Singapore & 6.94 & 5.75 & 5.09 & 5.61 & 5.91 & 4.17 & 4.6 & 4.33 & 3.64 & 2.94 & 2.22 & 2.07 & 2.04 \\
\hline Indonesia & 1.76 & 1.99 & 2.32 & 1.71 & 1.44 & 2.41 & 2.37 & 1.2 & 1.32 & 1.98 & 2.43 & 2.06 & 1.9 \\
\hline Egypt. Arab Rep. & 0.22 & 0.25 & 0.33 & 0.35 & 0.37 & 0.35 & 0.48 & 0.57 & 0.63 & 0.7 & 0.95 & 1.81 & 3.13 \\
\hline
\end{tabular}

Source: Trade Map International Trade statistics 


\section{Data and Methodology}

\subsection{Theoretical Model}

This article follows numerous authors and specifies the following gravity equation which controls for the basic determinants of international trade and the gravity model is a useful tool to examine the impact of trade cost on trade (Anderson \& Wincoop, 2004; Arivs et al., 2013; De, 2007; Khan \& Kalirajan, 2011). Moreover, the gravity model of trade has become the workhorse of international trade to estimate the relationship between distance (as a proxy for international transports costs) and export performance within the last decade (Kepaptsoglou et al., 2010). Hence, the author applies the equation (3) and proposes the model to estimate the impact of trade cost on export: A Case Study Vietnam. The functional form is as follow:

$$
\begin{array}{r}
\operatorname{LnEX}_{i j t}=\beta_{0}+\beta_{1} \operatorname{Ln}\left(\mathrm{GDP}_{\mathrm{it}}\right)+\beta_{2} \operatorname{Ln}\left(\mathrm{GDP}_{\mathrm{jt}}\right)-\beta_{3} \operatorname{Ln}\left(\mathrm{EC}_{\mathrm{ijt}}\right) \\
+\beta_{4} \operatorname{Ln}\left(\mathrm{OPEN}_{\mathrm{jt}}\right)+\beta_{5} \operatorname{Ln}\left(\mathrm{POP}_{\mathrm{jt}}\right)+\varepsilon_{\mathrm{ijt}}
\end{array}
$$

where $\mathrm{EX}_{\mathrm{ijt}}$ is the bilateral export value of Vietnam to country $\mathrm{j}$ in the time $\mathrm{t}$; $\mathrm{GDP}_{\text {it }}$ is the Gross domestic product of Vietnam in the time $t ; G P_{j t}$ is the Gross domestic product of country $j$ in the time $t$; $E C_{i j t}$ is the trade cost of Vietnam to country $j$ in the time $t$; OPEN $N_{j t}$ is the trade openness of country $j$ in the time $t ; P P_{j t}$ is the population of country $j$ in the time t. All variables are expressed in natural logarithm. Based on the gravity model we expect to find the coefficient of the GDP $\mathrm{it}_{\mathrm{it}}, \mathrm{GDP}_{\mathrm{jt}}, \mathrm{OPEN}_{\mathrm{jt}}, \mathrm{POP}_{\mathrm{jt}}$ to be positive and that of the $E C_{i j t}$ to be negative.

\subsection{Variable Descriptions}

Gross domestic product of country i $\left(G P_{i}\right)$ : An exporting country's real GDP also helps in ascertaining productive capacity of the exporting country, that is, the amount of the goods that could be supplied. In the gravity model, it is expected that an exporting country's GDP influences the export performance of goods and services originating from the exporting country, Tinbergen (1962) and Kepaptsoglo et al. (2010). The higher exporting country's GDP, the higher the export value from country $i$ to the world and country $j$. We expected a positive relationship between $\mathrm{GDP}_{\mathrm{i}}$ and $E \mathrm{X}_{\mathrm{ij}}$.

Gross domestic product of country $\mathrm{j}\left(\mathrm{GDP}_{\mathrm{j}}\right)$ : The gross domestic product of importing countries or trading partners is regarded as one of the primary indicators that are likely to influence the demand for export. GDPj was independent variable to control for size and income effects Tinbergen (1962) and Kepaptsoglo et al. (2010). For the purpose of the present study, $\mathrm{GDP}_{\mathrm{j}}$ represents the income of importing countries from country $i$. The higher the external demand or income of the trading partners, the higher the export value from country $i$ to country $j$. Thus, $E X_{i j}$ and $G P_{j}$ are expected to have a positive and significant relationship.

Trade cost $\left(E C_{i j}\right)$. There are several evidences that point to the impact of trade cost on trade performance particularly on export. Anderson and Wincoop (2004), De (2007), Khan and Kalirajan, (2011) and Arivs et al.(2013) indicated that the trade cost has a negative impact on export. The trade cost is also regarded as one of the primary indicators that are likely to influence the import demand of trading partners and export supply of exporting country. The higher trade cost from country $i$ to country $j$, the lower higher the export value from country $i$ to country $j$. Thus, $E X_{i j}$ and $E C_{i j}$ are expected to have a negative and significant relationship.

Trade openness of country $\mathrm{j}\left(\mathrm{OPEN} \mathrm{N}_{\mathrm{j}}\right.$ ): Trade openness ratio of the partner country $\mathrm{i}$, trade openness measurement, which is derived from the ratio trade over GDP, was tested with a hypothesis that the more an economy is open, the more it trades with the world and Vietnam. Kepaptsoglo et al. (2010). Thus, $E X_{i j}$ and OPEN $_{j}$ are expected to have a positive and significant relationship.

Population of country $\mathrm{j}(\mathrm{POPj})$ : Population is used to estimate the market size of each country which is a factor affecting international trade (Kepaptsoglo et al., 2010). The larger the market the more it trades, so the market size is expected to turn out with positive sign.

\subsection{Data Sources}

The research covers a total of 70 importing markets. These markets are chosen based on the importance of trading partnership with Vietnam and the availability of required data. There are United States of America, China, Japan, South Korea, Hong Kong, Indonesia, Malaysia, Philippine, Singapore, Thailand, Laos, Germany, United Kingdom, Australia, Netherlands, Cambodia, India, Italy, France, Canada and so on are included in our sample for the analysis of Vietnam exports during the period 2001-2013 (13 years). On the whole, the sample markets absorb at least $80 \%$ of Vietnam's total exports. The estimation covers 70 countries over the years 2001-2013 with one dependent variable and 5 explanatory variables (a total of observations $=910, \mathrm{~N}=70$, and $\mathrm{T}=13$ ), and all variables are expressed in natural logarithm. The panel series were sourced from the Trade Map International Trade statistics and World Bank database (World Development Indicators -WDI) (see Table 2). 
Table 2: Summary of Data Sources

\begin{tabular}{|c|l|l|}
\hline No. & \multicolumn{1}{|c|}{ Variables } & \multicolumn{1}{c|}{ Source } \\
\hline 1 & Export value from Vietnam to importing country $\mathrm{j}$ in year $\mathrm{t}\left(\mathrm{EX}_{\mathrm{it}}\right)$ & Trade Map International Trade statistics \\
\hline 2 & Trade cost from Vietnam to importing country $\mathrm{j}$ in year $\mathrm{t}\left(\mathrm{EC}_{\mathrm{ijt}}\right)$ & World Bank database $(\mathrm{WDI})$ \\
\hline 3 & Gross domestic product of Vietnam in year $\mathrm{t}\left(\mathrm{GDP}_{\mathrm{jt}}\right)$ & World Bank database $(\mathrm{WDI})$ \\
\hline 4 & Gross domestic product of importing country $\mathrm{j}$ in year $\mathrm{t}\left(\mathrm{GDP}_{\mathrm{jt}}\right)$ & World Bank database $(\mathrm{WDI})$ \\
\hline 5 & Population of importing country j in year $\mathrm{t}\left(\mathrm{POP}_{\mathrm{jt}}\right)$ & World Bank database $(\mathrm{WDI})$ \\
\hline 6 & Trade openness of importing country $\mathrm{j}$ in year $\mathrm{t}\left(\mathrm{OPEN}_{\mathrm{jt}}\right)$ & World Bank database (WDI) \\
\hline
\end{tabular}

\section{Results and Discussion}

Panel data sets are preferred in recent gravity model studies with only a handful of studies remaining on crosssectional models; advantages of panel data have been exploited by most researchers (Kepaptsoglo et al., 2010), (Khan \& Kalirajan, 2011), Arvis et al, 2013). The panel data technique has been used in this paper. Table 3 present correlation analyses for the main variables includes in the analysis. The correlation coefficients matrix reveals that most of the independent variables had low correlations (less than 0.7 ) with the dependent variables except for InGDPj (0.7404) and InECij (0.8374).

Table 3. Correlation Coefficient between the variables

\begin{tabular}{|c|c|c|c|c|c|c|}
\hline Variables & InEX $_{\mathbf{i j}}$ & InGDP $_{\mathbf{j}}$ & InPOP $_{\mathbf{j}}$ & InEC $_{\mathbf{i j}}$ & InOPEN $_{\mathbf{j}}$ & InGDP $_{\mathbf{i}}$ \\
\hline $\operatorname{InEX}_{\mathrm{ij}}$ & 1.0000 & & & & & \\
\hline $\operatorname{InGDP}_{\mathrm{j}}$ & 0.7404 & 1.0000 & & & & \\
\hline $\operatorname{InPOP}_{\mathrm{j}}$ & 0.5804 & 0.6341 & 1.0000 & & & \\
\hline $\operatorname{InEC}_{\mathrm{ij}}$ & -0.8374 & -0.5132 & -0.3923 & 1.0000 & & \\
\hline InOPEN $_{\mathrm{j}}$ & -0.0808 & -0.3516 & -0.5579 & -0.1353 & 1.0000 & \\
\hline $\operatorname{InGDP}_{\mathrm{i}}$ & 0.4067 & 0.1857 & 0.0332 & -0.3540 & 0.0940 & 1.0000 \\
\hline
\end{tabular}

The objective of the study was to estimates the impact of trade cost on Vietnamese export performance. The method used for estimating the model was a static linear panel analysis which consists of pooled ordinary least square regression (OLS), fixed and random effects. However, to choose the best model, several tests needed to be performed. The first test was the Breusch and Pagan Lagrangian multiplier (LM), which was used to choose between random effects and pooled OLS. The results from the Breusch-Pagan test indicated a preference for a random effects model to pooled OLS in the estimation model. As there are country-specific effects, the pooled OLS model shown in Table 4 was considered to be unacceptable. Then, the Hausman test was carried out to choose between random effects and fixed effects. The result in Table 4 clearly shows that the fixed effects model was the appropriate model $(p<0.05)$.

Before using the fixed effects model, it was necessary to perform a diagnostic test on the serial correlation. This was done by performing Wooldridge's serial correlation test. The null hypothesis of no first order autocorrelation is rejected if $p$ is less than 0.05 . The result was $p=0.0000$, which is smaller than 0.05 , indicating that there is a significant serial correlation of the residuals. Thus, the model was then reestimated using the Generalized Least Square (GLS) estimator for the fixed effects model. The GLS estimator provides the Best Linear Unbiased Estimator (BLUE). Thus, the final model for the inference of the fixed effects was based on the GLS estimator (see Table 5).

Table 4. Pooled OLS, Random Effects and Effects

\begin{tabular}{|c|c|c|c|}
\hline Variables & OLS & Random Effects & Fixed Effects \\
\hline Gross domestic product of importing country $\mathrm{j}\left(\operatorname{InGDP} \mathrm{j}_{\mathrm{j}}\right)$ & $0.4137389^{* * *}$ & $0.6038692^{* * *}$ & $0.9103753^{* * *}$ \\
\hline Population of importing country $\left.\mathrm{j}(\operatorname{lnPOP})_{\mathrm{j}}\right)$ & $0.2891917^{* * *}$ & $0.3224727^{* * *}$ & $1.240166^{\star * *}$ \\
\hline Trade cost from Vietnam to country j ( $\operatorname{lnEC_{ij})}$ & $-2.965792^{* \star *}$ & $-1.856053^{* * *}$ & $-1.617789^{* \star *}$ \\
\hline Trade openness of importing country $\mathrm{j}\left(\operatorname{InOPEN} \mathrm{N}_{\mathrm{j}}\right.$ ) & $0.2529936^{* * *}$ & $0.4456534^{* * *}$ & $0.5059724^{\star * *}$ \\
\hline Gross domestic product of Vietnam $\left(\operatorname{InGDP}_{\mathrm{i}}\right)$ & $0.6587991^{\star \star *}$ & $0.8247239^{\star \star \star}$ & $0.5817932^{\star \star \star}$ \\
\hline Constant & $-2.930277^{* *}$ & $-9.886976^{* * *}$ & $-17.90863^{\star * *}$ \\
\hline R-squared & 0.8592 & 0.8328 & 0.7142 \\
\hline Breush - Pagan test & $144.01(0.0000)$ & & \\
\hline Hausman test & & \multicolumn{2}{|l|}{$53.91(0.0000)$} \\
\hline Wooldrige's serial correlation test & & & $33.842(0.0000)$ \\
\hline No.of observations & 910 & 910 & 910 \\
\hline
\end{tabular}

Notes: Values in parentheses refer to standard error ${ }^{* * *},{ }^{* *}$ denote statistical significance at the $1 \%, 5 \%$ levels, respectively. 
Table 5. Fixed Effects GLS Model

\begin{tabular}{|c|c|}
\hline Variables & Coefficient \\
\hline $\begin{array}{l}\text { Gross domestic product of importing country } \mathrm{j} \\
\left(\operatorname{InGDP}_{\mathrm{j}}\right)\end{array}$ & $0.4137389^{\star \star \star}$ \\
\hline Population of importing country j ( (nPOPj $)$ & $0.2891917^{* \star \star}$ \\
\hline $\begin{array}{l}\text { Trade cost from Vietnam to importing } \\
\text { country } \mathrm{j}\left(\ln E C_{\mathrm{ij}}\right)\end{array}$ & $-2.965792^{\star \star *}$ \\
\hline $\begin{array}{l}\text { Trade openness of importing country j } \\
\left(\text { InOPEN } N_{j}\right)\end{array}$ & $0.2529936^{* \star \star}$ \\
\hline Gross domestic product of Vietnam (InGDP $)$ & $0.6587991^{\star \star \star}$ \\
\hline Constant & $-2.930277^{\star \star *}$ \\
\hline
\end{tabular}

Notes: Values in parentheses refer to standard error ${ }^{* * *}$ denote statistical significance at the $1 \%$ levels, respectively.

Table 5 shows that Trade cost from Vietnam to importing country j $\left(E C_{i j}\right)$, Population of importing country $\mathrm{j}\left(P O P_{j}\right)$, Trade openness of importing country $j\left(O P E N_{j}\right)$, Gross domestic product of importing country $\mathrm{j}\left(\mathrm{GDP}_{\mathrm{j}}\right)$ and Gross domestic product of Vietnam $\left(\mathrm{GDP}_{\mathrm{i}}\right)$ are statistically significant at the $1 \%$ level. All independent variables has a positive relationship with Vietnam bilateral export value, except for the Trade cost from Vietnam to importing country j (EC) had a negative relationship with Vietnam bilateral export value as expected.

Trade cost is one of the key factors determining Vietnamese bilateral export value. The findings show that trade cost has a significant impact on bilateral export value, whereby for every $1 \%$ increase in trade cost, Vietnamese export value to trading partners decreased by $2.965 \%$. A higher trade cost implies a lower potential demand for export from trading partners or importing countries. In Vietnam, Tran and Ngo (2015) and Pham and Nguyen (2015) used gravity models with panel data to estimate the impact of distance on Vietnamese agricultural export and Vietnamese bilateral export value (as a proxy international transport costs). The coefficients of log of distance were ($0.173)$ and $(-0.61)$. While this paper result is $(-2.9665)$, is far greater than the two previous studies. According to Anderson and Wincoop (2004) showed that of this $170 \%$ trade cost, $21 \%$ is attributable to international transport costs. Therefore, the result is reliable. This is an emerging point of this study in Vietnam.

\section{Conclusion and Recommendations}

The paper uses gravity model to estimate the impact of trade cost on Vietnamese bilateral export value. The empirical results derive from a static linear panel data analysis (fixed effects model) indicate that trade cost plays a crucial role in determining the export value that occurs between Vietnam and trading partners. Besides, population of importing country, trade openness of importing country, gross domestic product of importing country and gross domestic product of Vietnam are also significant determinants of Vietnamese bilateral export value. The results show that every $1 \%$ increase in trade cost, Vietnamese export value to trading partners decreased by $2.965 \%$.

By the definition mentioned above, the trade cost $\mathrm{ECij}=$ $E C i+E C t+E C j$. In order to increase the export value between Vietnam and its trading partners, the government and decision makers in Vietnam should attempt to improve ECi. ECi is the costs incurred in the exporting country which have main costs such as: Packaging cost, loading from warehouse cost, pre-carriage cost, export customs clearance cost, handling at departure cost, transaction costs and other costs. In Vietnam, ECi are relatively high. It was estimated to be approximately $20.9 \%$ of GDP. Nevertheless, the costs are still at higher level compare with other in the Southeast Asia region. The key costs associated with $\mathrm{ECi}$ are domestic transport costs (58\% of total ECi) (including loading from warehouse cost and Pre-carriage cost), handing at departure cost ( $21 \%$ of total ECi), storage cost ( $10 \%$ of total ECi), packaging cost $(8 \%$ of total ECi) and Port and customs cost ( $3 \%$ of total $\mathrm{ECi}$ ) in Vietnam (Blancas, 2014). The key policy implications emerging from the results of this study are as follows: First, the government and decision makers in Vietnam should be faster and more effective investment in trade infrastructure. Second, the government and decision makers in Vietnam should improve domestic transport costs, handing at departure cost, packaging cost, storage cost, Port and customs cost.

The limitations of this study are pertaining to the data set and estimation techniques. First, the sample size used in this study is limited to the number of 70 Vietnamese trading partners from 2001 to 2013. Because trade cost data of World Bank database are only available up for Vietnamese trading countries to 2013. Second, the study has not yet estimated the impact of trade cost on export of agricultural and industrial goods. As Anderson and Wincoop (2004) showed that the trade cost in agricultural goods are higher than in industrial goods. So, further study should attempt to estimates the impact of trade cost on both of them these areas.

\section{References}

Anderson, J. E. (1979). A Theoretical Foundation for the Gravity Equation. American Economic Review, 69(1), 106-116.

Anderson, J. E., \& Wincoop, E. V. (2003). Gravity with Gravitas: A Solution to the Border Puzzle. American 
Economic Review, 93(1), 170-192.

Anderson, J. E., \& Wincoop, E. V. (2004). Trade costs. Journal of Economic Literature, 42(3), 691-751.

Arvis, J.-F., Duval, Y., Shepherd, B., \& Utoktham, C. (2013). Trade Costs in the Developing World: 1995-2010. World Bank Policy Research Working Paper 6309, 337. Washington, DC: World Bank.

Bergstrand, J. H. (1985). The Gravity Equation in International Economic Foundations and Empirical Evidence. Review of Economics and Statistics, 67, 474-81.

Blancas, L. C., Isbell, J., Isbell, M., Tan, H. J., \& Tao, W. (2014). Efficient Logistics: A Key to Vietnam's Competitiveness. Directions in Development. Washington, DC: World Bank.

De, P. (2007). Impact of trade costs on trade: Empirical evidence from Asian countries. Chapter IX in ESCAP 281-307. New York: United Nations.

Deardorff, A. (1995). Determinants of Bilateral Trade: Does Gravity Work in a Neoclassical World?. NBER Working Papers No. 5377.

Helpman, E. (1987). Imperfect competition and international trade: Evidence from fourteen industrial countries. Journal of the Japanese and International Economies, 1(1), 62-81.

Kepaptsoglou, K., Karlaftis, M. G., \& Tsamboulas, D. (2010). The gravity model specification for modeling international trade flows and free trade agreement effects: A 10-year review of empirical studies. The Open Economics Journal, 3(2010), 1-13.

Khan, I. U., \& Kalirajan, K. (2011). The impact of trade costs on exports: An empirical modeling. Economic
Modelling, 28(3), 1341-1347.

Khan, P. R., Obstfeld, M., \& Melitz, M. (2012). International Economic ( $9^{\text {th }}$ Edition). Upper Saddle River, $\mathrm{NJ}$ : Prentice Hall.

McCallum, J. (1995). National Borders Matter: Canada-U.S. Regional Trade Patterns. American Economic Review, 85(3), 615-23.

Obstfeld, M., \& Rogoff, K. (2000). The six major puzzles in International Macroeconomics: Is there a common cause?. NBER Macroeconomics Annual 2000, 339390.

Pham, T. N., \& Nguyen, T. T. (2015). Factors influencing to Vietnamese seafood export to European and American market. Trade Science Review, 80, 10-19.

Ramber, J. (2011). ICC guide to Incoterms 2010: Understanding and practical use. International Chamber of Commerce. Paris, France: ICC services.

Roberts, M., \& Janson, M. (2014). Why trade costs matter: The 5th global review of aid for trade, Switzerland, Retrieved November 30, 2017, from http://www.tradeforum.org/news/Why-trade-costsmatter-the-5th-Global-Review-of-Aid-for-Trade/

Tinbergen, J. (1962). Shaping the World Economy: Suggestions for an International Economic Policy. New York: The Twentieth Century Fund.

Tran, N .K., \& Ngo, T. M. (2015). Factors influencing the export turnover of agricultural products in Vietnam: Analysis by gravity model. Journal of World Economics \& Politics, 3(227), 47-52. 